\title{
Identification of Leydig cell-specific mRNA transcripts in the adult rat testis
}

\author{
P J O'Shaughnessy, A Monteiro, P A Fowler ${ }^{1}$ and I D Morris ${ }^{2}$ \\ Division of Cell Sciences, Institute of Biodiversity, Animal Health and Comparative Medicine, University of Glasgow, \\ Bearsden Road, Glasgow G61 1QH, UK, ${ }^{1}$ Division of Applied Medicine, Institute of Medical Sciences, University of \\ Aberdeen, Aberdeen AB25 2ZD, UK and ${ }^{2}$ Hull York Medical School, The University of York, John Hughlings \\ Jackson Building, York YO10 5DD, UK
}

Correspondence should be addressed to PJ O'Shaughnessy; Email: peter.oshaughnessy@glasgow.ac.uk

\begin{abstract}
The adult population of Leydig cells acts to secrete testosterone which is essential for reproductive health and fertility in the adult male. However, other physiological functions of these cells are uncertain, and to address this issue a cell ablation model has been used to identify Leydig cell-specific mRNA transcripts. Ethane dimethane sulphonate (EDS) was synthesised by a novel process and was used to ablate Leydig cells in adult male rats previously treated with butane dimethane sulphonate (busulphan) to delete the germ cell population. Levels of mRNA transcripts were measured in the testis using microarrays 1, 3, 5, 8 and 12 days after EDS injection. During this period, there was a significant change in the levels of $\mathbf{2 2 0 0}$ different transcripts with a marked decline in the levels of canonical Leydig cell transcripts, such as Cyp11a1, Cyp17a1 and Insl3. A total of 95 transcripts showed a similar decline in expression after EDS treatment, suggesting that they have a Leydig cell-specific origin. Analysis of selected transcripts confirmed that they were expressed specifically in Leydig cells and showed that most had a late onset of expression during adult Leydig cell development. Apart from transcripts encoding components of the steroidogenic apparatus, the most common predicted function of translated proteins was endogenous and xenotoxicant metabolism. In addition, a number of transcripts encode acute-phase proteins involved in reduction of oxidative stress. Results show that, in addition to androgen secretion, Leydig cells may have a critical role to play in protecting the testis from damage caused by toxicants or stress.

Reproduction (2014) 147 671-682
\end{abstract}

\section{Introduction}

During testicular development, two populations of Leydig cells arise sequentially. The foetal population differentiates soon after the start of testis development and is responsible for foetal androgen production and induction of masculinisation. In rodents, the foetal population is replaced shortly after birth by a second 'adult' population that maintains testicular androgen production throughout the adult lifespan of the animal. These two populations appear to represent distinct cell lineages and show clear differences in their regulation and pattern of development. The adult population starts to develop around postnatal day 12 in the rat (Ariyaratne et al. 2000) and days 7-10 in the mouse (Baker etal. 1999, Nef etal. 2000). Thereafter, cell numbers increase rapidly in the immediate pre-pubertal period, so that by day 30 both Leydig cell numbers and androgen production are close to adult levels (Vergouwen et al. 1993, Baker \& O'Shaughnessy 2001a, O'Shaughnessy et al. 2002, Baker et al. 2003a). The primary function of the adult Leydig cell population is to secrete androgens that are essential for both somatic cell function and germ cell development in the testis and for the development and maintenance of the male phenotype and sexual behaviour. It is less clear, however, whether the adult Leydig cells have other functions in either testis biology or systemic metabolism. To understand the role of the Leydig cell, a comprehensive list of transcripts strongly and uniquely expressed in these cells is a prerequisite. Previous studies have generated lists of transcripts expressed in Leydig cells by microarray analysis of isolated cells (Stanley et al. 2011). While these lists are of considerable value, most of the transcripts present are expressed in multiple cell types, so that identifying Leydig cell-specific transcripts can be complex. A recent alternative method has been developed to analyse transcripts in ribosomes specific to the Leydig cells and through this to identify transcripts enriched in the Leydig cell population (Sanz et al. 2013). In this study, we have taken a different complementary approach - in order to identify genes specifically expressed in the adult Leydig cell population, we used the cytotoxic agent ethane dimethane sulphonate (EDS). In adult rats, a single injection of EDS leads to rapid (mostly within $24 \mathrm{~h}$ ) and complete ablation of the adult Leydig cell population (Kerr et al. 1985, Morris et al. 1986). Using microarrays, we followed the changes in testis mRNA transcript levels after EDS 
injection in order to identify specific transcript species that are markedly reduced over the period of Leydig cell ablation. A potentially confounding factor when using the standard EDS model for this purpose would be the related degeneration of the androgen-dependent spermatogenic epithelium following EDS treatment. To circumvent this problem, we have recently refined the EDS model using butane dimethane sulphonate (busulphan) to generate a germ cell-free testis, which can be used to study Leydig cell ablation in comparative isolation $\left(\mathrm{O}^{\prime}\right.$ Shaughnessy et al. 2008a). Results from the microarray and post-array analyses suggest that the Leydig cells are likely to play a role in protecting the testis from xenotoxicant action along with their established steroidogenic function.

\section{Materials and methods}

\section{Synthesis of EDS}

EDS is not commercially available and has previously been synthesised as described by Jackson \& Jackson (1984). For this study, a novel preparation method was used: ethylene glycol (10 g, dry) was mixed slowly with methane sulphonyl chloride $(16 \mathrm{ml})$ in a flask cooled in ice. Triethylamine $(40 \mathrm{ml})$ was then added dropwise with constant stirring to the cooled mixture, which will turn semisolid. The reaction mixture was allowed to stand at $15-20^{\circ} \mathrm{C}$ for $2-3 \mathrm{~h}$ and a mixture of concentrated sulphuric acid $(40 \mathrm{ml})$ and crushed ice $(500 \mathrm{ml})$ was carefully prepared in a separate vessel. Small amounts of this ice-cold mixture were titrated slowly into the main reaction vessel until excess triethylamine was neutralised and EDS appeared as white crystals. EDS will become a viscous liquid if the mixture is allowed to warm up. The crystals were filtered and washed with ice-cold water, then recrystallised from hot $\left(55^{\circ} \mathrm{C}\right)$ methanol.

\section{Animals and animal treatments}

Adult Sprague-Dawley rats (250-300 g) were purchased from Harlan UK (Bicester, Oxon, UK). The germ cell population was ablated as described previously (O'Shaughnessy et al. 2008a) by two injections (i.p.) of busulphan $(10 \mathrm{mg} / \mathrm{kg})$ spaced 4 weeks apart. Six weeks after the second injection of busulphan, the animals were injected (i.p.) with EDS $(100 \mathrm{mg} / \mathrm{kg})$ or vehicle. Animals (3-5 per group) were killed by $\mathrm{CO}_{2}$ inhalation at $1,3,5$, 8, 12 and 20 days after EDS treatment. Control animals were injected with only vehicle. For developmental studies, rats were bred in-house and normal, untreated animals killed on days 1, 2, 4, 5, 7, 10, 12, 14, 17, 20 and 90 (adult). In all cases, one testis from each animal was processed immediately for RNA extraction while the other testis was weighed, cut in half and one halffixed in Bouin's solution while the other half was frozen rapidly in liquid $\mathrm{N}_{2}$ and stored at $-20^{\circ} \mathrm{C}$. All animal procedures were carried out under UK Home Office licence and with local ethical approval.

\section{RNA extraction}

To extract RNA, whole testes were homogenised in TRIzol (Invitrogen Ltd). In studies designed to measure transcript expression through real-time PCR, luciferase mRNA (Promega UK) was added to the samples at the time of RNA extraction and subsequently used as an external standard in real-time assays (Baker \& O'Shaughnessy 2001b, Johnston et al. 2004). For array studies, the RNA was further processed using RNeasy kits (Qiagen Ltd) according to the manufacturer's instructions.

\section{Microarray}

The quality of the RNA was assessed with an Agilent RNA bioanalyser and samples of $10 \mu \mathrm{g}$ total RNA were reverse transcribed and then in vitro transcribed according to the Affymetrix standard protocols. The Affymetrix (Affymetrix, Santa Clara, CA, USA) rat genome 2302.0 arrays were used in all hybridisations.

\section{Quantitative PCR}

Extracted RNA was reverse transcribed using random hexamers and Moloney murine leukaemia virus reverse transcriptase (Superscript II, Invitrogen Ltd) as described previously (O'Shaughnessy \& Murphy 1993, O'Shaughnessy \& Mannan 1994). Transcript levels were measured by real-time PCR using the SYBR green method with a Stratagene MX3000 cycler (O'Shaughnessy \& Murphy 1993, O'Shaughnessy et al. 2008b). Levels of transcript were expressed relative to the level of the external luciferase control or against the housekeeping gene Sdha. Measurement relative to an external standard allows transcript levels to be expressed on a per testis basis and this method was used for developmental studies while expression relative to an internal housekeeping gene was used to compare expression with array data (Baker \& O'Shaughnessy 2001b, Baker et al. 2003b). All primers were designed using Primer Express 2.0 (Applied Biosystems) with parameters described previously (Czechowski et al. 2004).

\section{Immunohistochemistry}

Testes were fixed overnight in Bouin's solution and stored in $70 \%$ ethanol. Wax sections $(5 \mu \mathrm{m})$ were incubated with primary antibody overnight at $4{ }^{\circ} \mathrm{C}$ and endogenous biotin was blocked using an avidin/biotin blocking kit (R\&D Systems Europe Ltd, Abingden, UK). The antibodies used were CYP11A1 (anti-rabbit, gift from Dr A H Payne, University of Stanford, USA), (CES3) (sc-82555, Santa Cruz Biotechnology, Inc.), AQP9 (AQP91-A, Autogen Bioclear UK Ltd, Wiltshire, UK), CXCL12 (MAB350, R\&D Systems Europe Ltd) and EH (gift from Prof. Dr Ulrich M Zanger, Dr Margarete Fischer Bosch Institute of Clinical Pharmacology, Germany). The sections were washed and incubated for $30 \mathrm{~min}$ with biotinylated secondary antibody (R\&D Systems Europe Ltd). Bound primary antibody was detected using a peroxidase-conjugated secondary antibody, followed by a fluorescyl-tyramide amplification step with visualisation using 3,3-diaminobenzidine tetrahydrochloride (Dako UK Ltd, Cambridgeshire, UK). For negative-control samples, non-immune serum replaced primary antiserum. 


\section{Statistical analysis}

Microarray data from two independent samples from animals killed at $0,1,3,5,8$ and 12 days after EDS treatment were analysed initially by the robust multichip average method using the BioConductor microarray analysis software (Irizarry et al. 2003), while differentially expressed genes were identified using RankProducts (Breitling et al. 2004). Transcripts were considered to show a significant change if signal strength at one time point after EDS treatment was $>100$ and there was an overall false discovery rate $(F D R)<5 \%$ considering all time points and/or a more than twofold difference in expression at a single time point with FDR $<10 \%$. Database and spreadsheet comparisons were carried out using a relational database (Access, Microsoft Corp.). Further analysis of potential interactions between transcripts was partly carried out using Ingenuity Pathways Analysis (www. ingenuity.com), Build version: 220217 with relationships included where experimentally confirmed. Data from real-time PCR studies were analysed by single-factor ANOVA followed by Fisher's multiple comparison test (Minitab, Minitab, Inc.). Where necessary, data were log-transformed before analysis to remove heterogeneity of variance.

\section{Results}

\section{Effects of EDS}

Changes in testis histology and testosterone levels following EDS treatment in this model have been described previously (O'Shaughnessy et al. 2008a).

\section{Identification of Leydig cell transcripts}

Following ablation of Leydig cells by EDS treatment of germ cell-free rats, there was a significant change in the levels of 2200 transcripts over a 12-day period (Supplementary Table 1, see section on supplementary data given at the end of this article). Of these, 1103 transcripts were consistently reduced in expression at all time periods. It might be expected that most of the transcripts that show a marked and sustained decline in expression after EDS treatment will be of a Leydig cell origin although a number will be androgen dependent transcripts expressed in other somatic cells. In addition, transcripts that are expressed in Leydig cells and in at least one other cell type will decline after EDS treatment as the Leydig cells are ablated, but the overall decline will be less marked. In order to identify genes that are most likely to be Leydig cell specific, parameters were set based on the expression of canonical Leydig cellspecific transcripts. Changes in transcript levels of some of these known Leydig cell genes following EDS treatment are shown in Fig. $1 \mathrm{~A}$ and confirm the expected rapid loss of transcripts. To identify other Leydig cellspecific transcripts, the following constraints, based on the canonical transcripts, were applied: i) levels must have reduced by $40 \%$ or more during the first $24 \mathrm{~h}$ after EDS treatment; ii) transcript levels must have
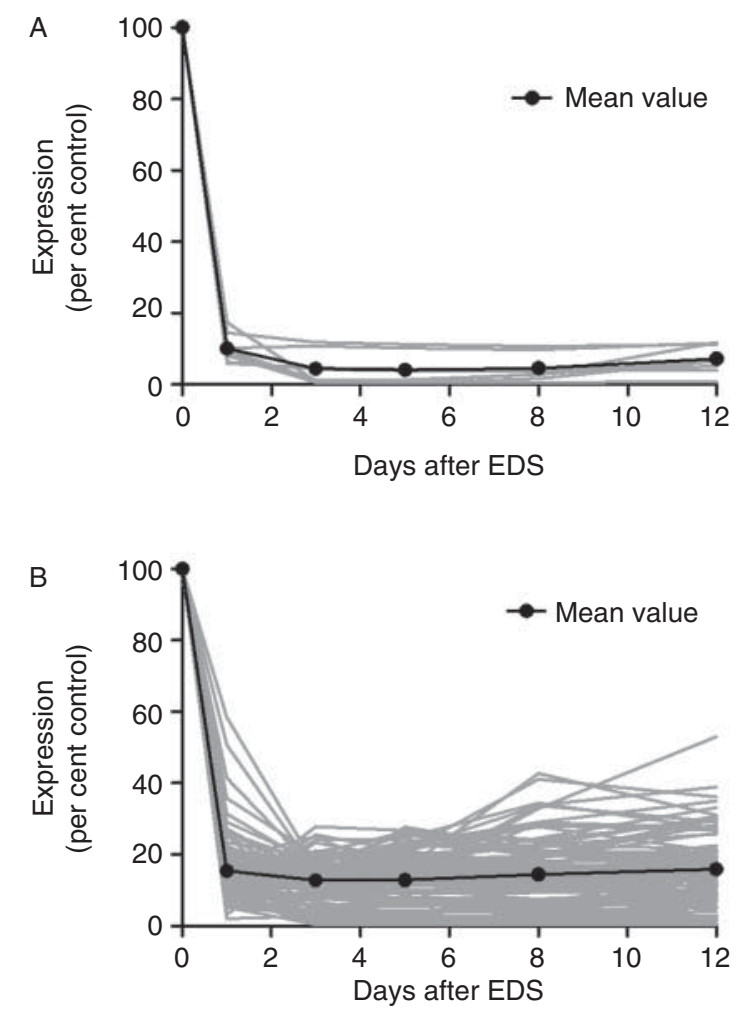

Figure 1 Microarray data showing relative changes in expression of known and putative Leydig cell transcripts. (A) Expression data from eight Leydig cell-specific transcripts following EDS treatment. The transcripts were Hsd3b, Cyp17a1, Cyp11a1, Lhcgr, Ins/3, Hsd17b3, Gnrhr, Hmgcs2. (B) Expression data from 93 putative Leydig cell transcripts shown in Supplementary Table 2. Individual transcripts are shown with a grey line and the mean value is shown in black.

fallen below $20 \%$ of control within $5 \mathrm{~d}$ and iii) average levels between $3 \mathrm{~d}$ and $8 \mathrm{~d}$ after EDS treatment must have been below $30 \%$ of control. While these constraints are arbitrary, they were carefully designed specifically to include known Leydig cell-specific transcripts. Overall, 93 transcript species fulfilled these criteria, including the major steroidogenic enzymes, the luteinizing hormone (LH) receptor and insulin-like growth factor 3 (Ins/3) but excluding Star (discussed below). Expression changes in these 93 transcripts are shown in Fig. 1B and the top 25 genes are listed in Table 1 in ascending order of expression on day 3 after EDS treatment. The nearer to the top that a transcript appears in Table 1, therefore, the lower the relative expression on day 3 after EDS treatment and the more likely it is to be specifically expressed in the Leydig cell. The complete list of 93 transcripts is shown in Supplementary Table 2.

\section{Comparison to other testicular cell transcript databases}

Microarray analysis of transcripts from isolated adult rat Leydig cells by Stanley et al. (2011) showed the presence of 16713 specific species (not allowing for duplicates on 
Table 1 Top 25 genes identified as Leydig cell specific.

\begin{tabular}{|c|c|c|c|c|c|c|c|c|c|}
\hline \multirow[b]{2}{*}{ Affymetrix } & \multirow[b]{2}{*}{ GenBank } & \multirow[b]{2}{*}{ Symbol } & \multirow[b]{2}{*}{ Gene } & \multirow{2}{*}{$\begin{array}{l}\text { Control (raw } \\
\text { expression) }\end{array}$} & \multicolumn{5}{|c|}{$\begin{array}{c}\text { Expression (per cent control) after EDS } \\
\text { treatment }\end{array}$} \\
\hline & & & & & $1 d$ & $3 d$ & $5 d$ & $8 d$ & $12 d$ \\
\hline 1387139_at & NM_032082 & Hao2 & $\begin{array}{l}\text { Hydroxyacid oxidase } 2 \\
\text { (long chain) }\end{array}$ & 9678 & 5.33 & 0.45 & 0.31 & 0.30 & 0.31 \\
\hline 1387034_at & NM_012619 & Pah & Phenylalanine hydroxylase & 4450 & 8.02 & 0.61 & 0.54 & 0.58 & 0.56 \\
\hline 1387123_at & NM_012753 & Cyp17a1 & $\begin{array}{l}\text { Cytochrome P450, family } \\
\text { 17a1 }\end{array}$ & 6904 & 8.19 & 0.63 & 0.54 & 1.73 & 6.65 \\
\hline 1370363_at & L46791 & ${ }^{\mathrm{a}} \operatorname{Ces} 3 / \operatorname{Ces} 1 d$ & Carboxylesterase 3 (1d) & 10226 & 15.24 & 0.74 & 0.47 & 0.49 & 0.71 \\
\hline 1388241_at & AF139918 & Insl3 & Insulin-like 3 & 10447 & 17.39 & 0.98 & 0.65 & 0.67 & 0.82 \\
\hline 1368578_at & NM_017265 & Hsd3b1 & $\begin{array}{l}\text { Hydroxysteroid dehydro- } \\
\text { genase- } 1, \Delta 5-3 \beta\end{array}$ & 5826 & 8.52 & 1.28 & 1.09 & 2.95 & 11.78 \\
\hline 1368468_at & NM_017286 & Cyp11a1 & $\begin{array}{l}\text { Cytochrome P450, family } \\
\text { 11a1 }\end{array}$ & 4896 & 9.70 & 1.36 & 1.26 & 2.85 & 7.01 \\
\hline 1370964_at & BF283456 & Ass1 & Arginosuccinate synthetase & 6673 & 19.45 & 1.57 & 1.17 & 1.42 & 2.53 \\
\hline 1370148_at & NM_012582 & $H p$ & Haptoglobin & 7192 & 12.24 & 1.88 & 1.75 & 1.65 & 1.65 \\
\hline 1388176_at & Al717047 & $\mathrm{Cm} / 5$ & Camello-like 5 & 1194 & 2.08 & 2.74 & 2.77 & 2.61 & 2.87 \\
\hline 1370065_at & NM_053318 & Hрx & Haemopexin & 2648 & 9.06 & 3.02 & 2.30 & 2.11 & 2.23 \\
\hline 1368621_at & NM_022960 & Aqp9 & Aquaporin 9 & 2907 & 5.53 & 3.02 & 2.16 & 3.17 & 3.04 \\
\hline 1378133_at & AW532618 & Slc7a11 & $\begin{array}{l}\text { Solute carrier family } 7 \text {, } \\
\text { member } 11\end{array}$ & 1967 & 25.36 & 3.29 & 3.45 & 4.60 & 7.43 \\
\hline 1387465_a_at & NM_031038 & Gnrhr & $\begin{array}{l}\text { Gonadotrophin-releasing } \\
\text { hormone receptor }\end{array}$ & 1043 & 6.25 & 4.26 & 3.87 & 3.87 & 4.03 \\
\hline 1387423_at & NM_012978 & Lhcgr & $\begin{array}{l}\text { Luteinizing hormone/ } \\
\text { choriogonadotrophin } \\
\text { receptor }\end{array}$ & 615 & 5.95 & 4.69 & 4.25 & 4.31 & 5.10 \\
\hline 1387973_at & U39206 & Cyp4f4 & $\begin{array}{l}\text { Cytochrome P450, family } \\
4 \mathrm{f} 4\end{array}$ & 678 & 9.44 & 5.42 & 5.59 & 6.19 & 5.51 \\
\hline 1385500_at & BF400284 & LOC500945 & $\begin{array}{l}\text { Similar to } 1700012 \text { B09 } \\
\text { Rn.59584 }\end{array}$ & 758 & 9.77 & 5.82 & 3.86 & 6.96 & 10.79 \\
\hline 1369136_at & NM_012542 & Сур2а3 & $\begin{array}{l}\text { Cytochrome P450, } \\
\text { subfamily IIA3 }\end{array}$ & 501 & 8.78 & 5.99 & 6.39 & 6.19 & 5.59 \\
\hline 1392664_at & BF551274 & Gpr182 & $\begin{array}{l}\text { G protein-coupled receptor } \\
182 \text { (adrenomedullin } \\
\text { receptor) }\end{array}$ & 466 & 5.79 & 6.01 & 5.58 & 6.01 & 7.08 \\
\hline 1368990_at & NM_012940 & Cyp1b1 & $\begin{array}{l}\text { Cytochrome P450, family } \\
\text { 1b1 }\end{array}$ & 7824 & 5.92 & 6.02 & 3.59 & 5.52 & 7.39 \\
\hline 1367857_at & NM_053445 & Fads1 & Fatty acid desaturase 1 & 5010 & 12.75 & 6.85 & 2.99 & 6.39 & 14.85 \\
\hline 1367689_a_at & AF072411 & Cd36 & CD36 molecule & 5232 & 7.15 & 7.39 & 10.25 & 7.44 & 5.31 \\
\hline 1388037_at & J05087 & Atp2b3 & $\begin{array}{l}\text { ATPase, Ca }++ \text { transport- } \\
\text { ing, plasma membrane } 3\end{array}$ & 759 & 8.72 & 7.48 & 12.37 & 10.50 & 8.19 \\
\hline 1381920_at & AI502118 & & Transcribed locus & 634 & 9.89 & 7.65 & 6.91 & 7.61 & 7.53 \\
\hline 1371100_at & AA859049 & Ces1c & Carboxylesterase 1C & 712 & 12.64 & 7.72 & 6.46 & 7.02 & 8.71 \\
\hline
\end{tabular}

${ }^{\mathrm{a}}$ Rat Ces $1 d$ was previously called Ces3 and is orthologous to mouse Ces3 (Holmes et al. 2010).

the arrays). Most of these transcripts will not be unique to the Leydig cells, but a degree of specificity can be estimated by determining the relative enrichment of these transcripts in comparison to our control wholetestis arrays. If a transcript shows some specificity to the Leydig cells (i.e. it is expressed at a higher level in the Leydig cells than in other cells), it would be expected that relative expression in the Leydig cell arrays would be higher than the whole-testis arrays. Comparing all transcripts in the Leydig cell array with the whole-testis arrays, the median ratio of (Leydig cell):(whole-testis) transcript expression was 0.25 , so that any value above this would be consistent with at least some specific localisations in the Leydig cells. The average ratio for all 93 transcripts in Supplementary Table 2 is 1.03 (median 0.86 ) and only three have a ratio $<0.25$. This is consistent with a predominant Leydig cell expression of transcripts listed in Table 1. Stanley et al. (2011) also identified
42 genes upregulated during Leydig cell development and, of these genes, 17 are also included in Supplementary Table 2, including eight of the top 11 genes we identified. When the same 42 genes identified by Stanley (2011) were compared with the full list of transcripts significantly altered by EDS (Supplementary Table 1), the number of matches increased to 23 although most of the additional six matches showed either low expression or complex changes in expression after EDS treatment (Supplementary Table 3, see section on supplementary data given at the end of this article).

A recent report which analysed the Leydig and Sertoli 'translatome' (polysome-associated mRNAs) has identified 2608 transcripts, which are enriched in mouse Leydig cells (Sanz et al. 2013). Comparison of genes in Supplementary Table 2 with those identified as Leydig cell specific by Sanz et al. (2013) showed that just over half of Supplementary Table 2 (55\%) appears in both 
databases. More surprisingly, of the top 50 transcripts identified as Leydig cell specific by Sanz et al. (2013), only 18 were significantly altered by EDS treatment (Supplementary Table 4, see section on supplementary data given at the end of this article) and only six met the criteria for inclusion in Supplementary Table 2 of this study. Expanding the examination to include all 2608 genes in the Sanz et al. (2013) dataset identified 300 genes that are also included in Supplementary Table 1. Many of these 300 genes, however, showed no consistent and marked decline in expression after EDS treatment (Supplementary Table 5, see section on supplementary data given at the end of this article).

Transcript expression in isolated rat Sertoli cells and germ cells, measured using microarrays, has been described by Johnston et al. (2008). In order to compare these databases with the putative Leydig cell transcripts described here, the ratio of Sertoli cell or germ cell expression to whole-testis expression was determined for each transcript. As with the Leydig cell arrays from Stanley et al. (2011) described above, this then serves as a measure of the likelihood of that transcript showing higher-/lower-than-average expression in those cells. Comparing all 31000 transcripts on the arrays, the median ratios for transcript expression in Sertoli cells, round spermatids, pachytene spermatocytes and combined spermatogonia plus early spermatocytes relative to the whole testis were $0.74,0.96,1.01$ and 1.18 respectively. Values for each of the putative Leydig cell genes are shown in Supplementary Table 2. With respect to round spermatids and pachytene spermatocytes, most of the Leydig cell transcripts listed in Supplementary Table 2 had values less than the median suggesting low to very low levels of expression in these cell types. A small number of transcripts (e.g. Rab33a and Tekt3) showed expression ratios higher than the median for one or both germ cell types making it likely that these transcripts are expressed in both Leydig cells and germ cells. With respect to array data from Sertoli cells and combined spermatogonia plus early spermatocytes, many of the Leydig cell transcripts in Supplementary Table 2 showed expression ratios greater, and in some cases markedly greater, than the median. This included canonical Leydig cell genes such as Hsd3b1, Cyp17a1 and Cyp11a1, suggesting that the isolated Sertoli cells and combined spermatogonia plus early spermatocytes used to generate the arrays contained a significant number of Leydig cells. This means, unfortunately, that the calculated ratios are not helpful in assessing likely transcript expression in these particular cell types.

\section{Real-time PCR of transcript levels after EDS treatment}

To confirm the array data shown in Table 1, the expression of selected transcripts following EDS treatment was measured by real-time PCR (Fig. 2). The data in Fig. 2A shows the expression pattern of three individual canonical Leydig cell-specific transcripts. Comparison of these with the putative Leydig cell transcripts in Fig. 2B confirms the same general pattern of expression after EDS treatment. The major difference between Fig. $2 \mathrm{~A}$ and $\mathrm{B}$ is that some of the transcripts in Fig. 2B have higher levels of residual transcript remaining after EDS treatment, which probably indicates the presence of some low expression in other testicular cell types. Changes in Star transcript levels are shown in Fig. 2C. This gene might have been expected to have the same pattern of expression as other canonical Leydig cell genes in Fig. 2A but shows, instead, a gradual decline in transcript levels whether measured by array or real-time PCR. Also shown in Fig. 2C is Tbp which is a ubiquitous cellular transcript and serves as a positive control. It should be noted that in all cases there was good correlation between data from arrays and real-time PCR.

To measure the recovery of transcript levels as the Leydig cells regenerate following EDS treatment, samples were taken $20 \mathrm{~d}$ after treatment and expression of the transcripts shown in Fig. 2 was compared with controls by real-time PCR (Fig. 3). Levels of the canonical transcripts Cyp11a1, Hsd3b and Cyp17a1 returned to normal or close to normal by day 20 as suggested previously (O'Shaughnessy et al. 2008a). Expression of the other putative Leydig cell transcripts showed some recovery by day 20 after EDS treatment, but all remained clearly lower than control levels.

\section{Developmental changes in Leydig cell transcripts}

The slow recovery of transcript levels shown in Fig. 3 suggested that many of the putative Leydig cell transcripts identified in Table 1 may be expressed relatively late in Leydig cell development. To examine this possibility, and to determine if any of the transcripts are specific only to the 'adult' population of Leydig cells, transcript levels were measured by real-time PCR relative to an external standard during development in normal rats after birth (Fig. 4). Canonical Leydig cell transcripts were detectable at all ages and either reached adult levels by 20 days (Hsd3b and Cyp17a1) or were within $50 \%$ of adult levels at that age (Cyp11a1). Most of the putative Leydig cell transcripts were also detectable at all ages but expression at $20 \mathrm{~d}$ was $<10 \%$ of adult levels in most cases indicating late onset of expression. One transcript, Pah, was largely undetectable before $20 \mathrm{~d}$ (Fig. 4), indicating that it is expressed only in the adult Leydig cells. Expression of Ces1d was unusual as it showed a small peak of activity at day 7 , then declined to undetectable levels at day 17 before increasing again at puberty.

\section{Immunohistochemistry}

Localisation of proteins from selected genes in Table 1 was determined by immunohistochemistry using normal adult 

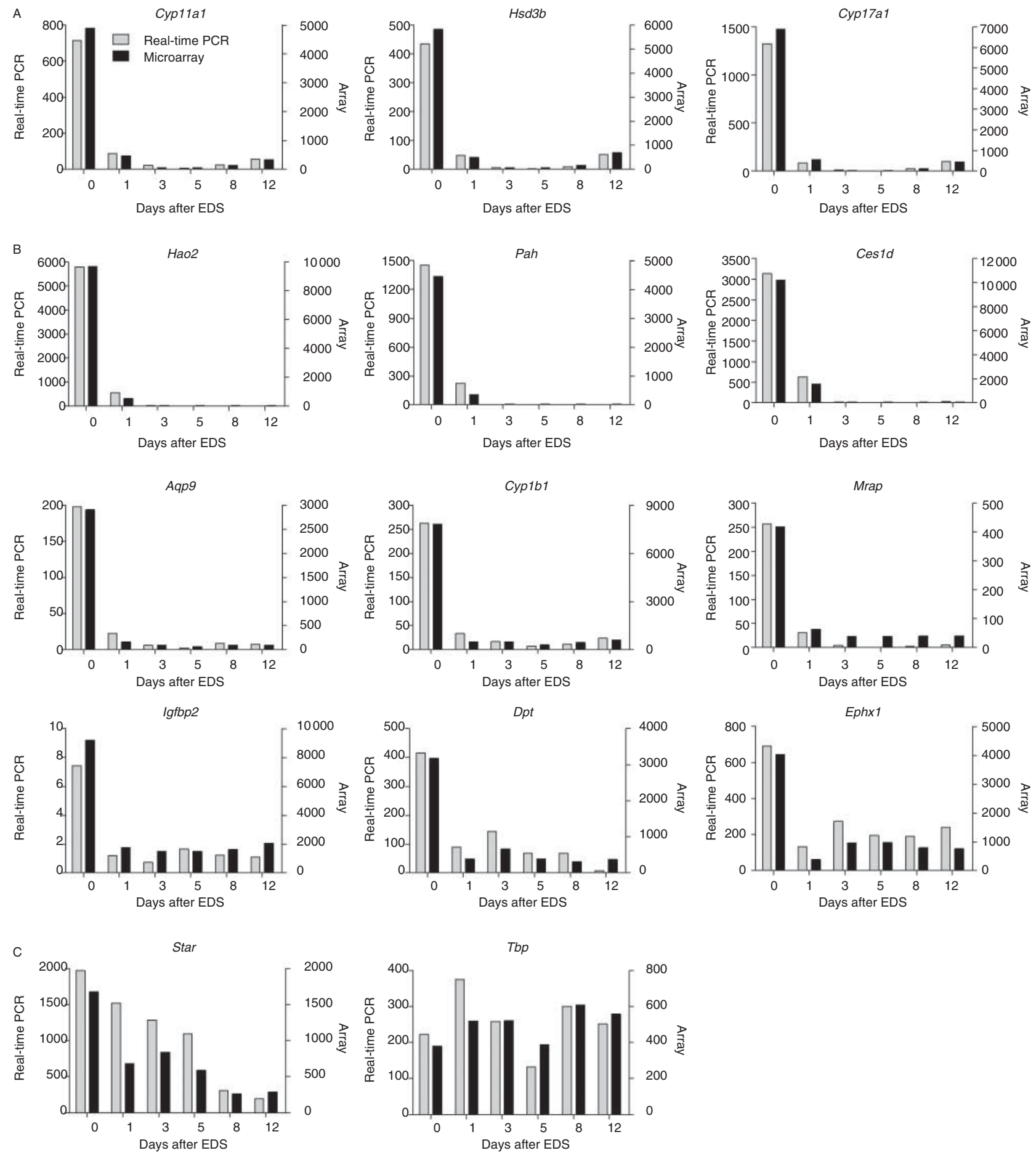

Figure 2 Comparison of microarray data from selected transcripts with results from real-time PCR. Transcript levels were measured in adult rat testis after EDS treatment using microarrays or by real-time PCR, expressed relative to an internal housekeeping gene Sdha. Results show the mean of duplicate animals used at each point for array studies and three to five animals used for real-time PCR. The transcripts are divided into those recognised as canonical Leydig cell transcripts (A), putative Leydig cell transcripts in Supplementary Table 2 (B) and others (C) which include the positive-control Tbp.

rat testes (Fig. 5). Results show that CES1D and AQP9, both ranked highly in Table 1, are clearly expressed in the Leydig cells with little or no expression in other cell types. EPHX1, which is ranked towards the bottom of Table 1, is also predominantly expressed in the Leydig cells although low levels of expression were also seen in some elongating spermatids (Fig. 5). One of the more surprising transcripts in Table 1 and Supplementary Table 2 is Cxc/12 which has 


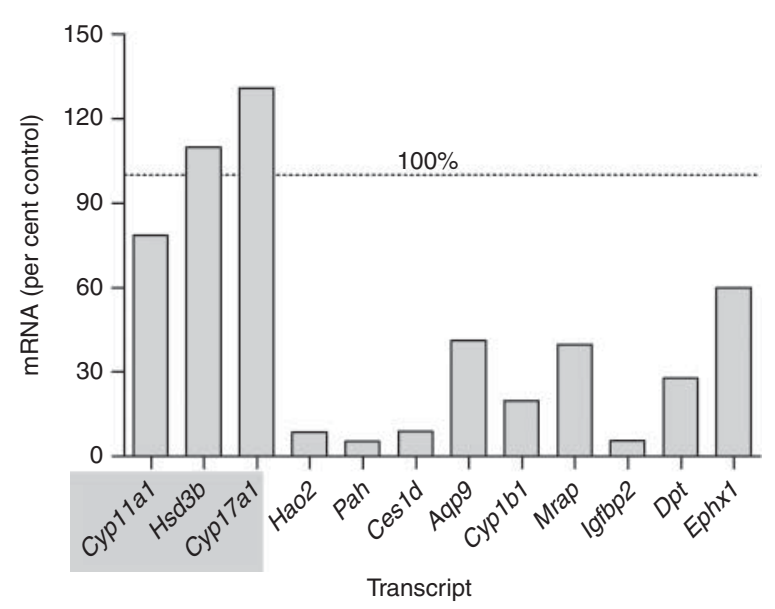

Figure 3 Recovery of transcript expression following EDS treatment. Transcript levels were measured by real-time PCR 20 days after EDS treatment. Mean expression $(n=3)$, relative to control (non-treated) values is shown. Three canonical Leydig cell genes are highlighted by a grey box.

previously been reported to be expressed predominantly in the mouse Sertoli cell (Gilbert et al. 2009, Payne et al. 2010, Yang et al. 2013). Immunohistochemistry shows, however, that this chemokine is expressed only in the interstitial tissue and mainly in the Leydig cells in the control adult rat testis with some expression also in endothelial cells. Expression of CYP11A1 in the adult Leydig cells is also shown in Fig. 5 as a positive control.

\section{Discussion}

The Leydig cells are part of an integrated cellular system in the testis that ensures male fertility. While the primary function of the Leydig cells is to secrete androgen, it is likely that they also play other roles in the maintenance of testicular homoeostasis and optimisation of male reproduction. Previous studies have shown that Leydig cells synthesise several enzymes and growth factors not directly involved in steroidogenesis. These include INSL3 (Pusch et al. 1996), inhibin/activin subunits (Roberts et al. 1989), PTGDS (Baker \& O'Shaughnessy 2001a), NUCB2 (Garcia-Galiano et al. 2012), epoxide hydrolase and glutathione $S$-transferases (Ishii-Ohba et al. 1984, Coller et al. 2001), indicating a number of different activities that may be associated with the cells. To gain a detailed understanding of all aspects of Leydig cell function both within the context of the testis and systemically, however, it is necessary to establish a list of genes/proteins expressed specifically in these cells. This process has already begun (Stanley et al. 2011, Sanz et al. 2013) and results from the present study both confirm and challenge the previous findings and extend the likely repertoire of Leydig cell activity.

The Leydig cell transcriptome and/or Leydig cellspecific transcripts have been described recently using microarrays of purified isolated cells or by looking for transcript enrichment in Leydig cell-specific ribosomes. Stanley et al. (2011) have used cell isolation techniques, followed by microarrays, to identify the transcripts in adult rat Leydig cells at different stages of development. This technique provides a global view of cell transcript expression although the quality of the resultant data is dependent upon the purity of the isolated cells and the effects of the isolation technique on transcript expression. As the transcriptome of these cells contains over 16000 different transcript species, it is important to use filtering techniques being able to identify genes of interest and this was achieved using a developmental approach. The strategy used by Sanz et al. (2013) avoided the necessity for cell isolation and generated a Leydig cell translatome using an in vivo ribosome tagging technique which allowed polysome-associated mRNAs from Leydig cells to be characterised. Identification of Leydig cell-specific transcripts was achieved by determining relative enrichment compared with total input mRNAs. This approach is extremely powerful if the Cre promoter used is specific to the cell of interest and in this case the Cyp17iCre was shown to be largely expressed in the Leydig cells although some tubular expression was also seen. The EDS-induced cell ablation approach used in this study also does not rely on cell isolation techniques and offers the advantage of being able to identify transcripts largely or exclusively expressed in the cell of interest. There are, however, a number of caveats with this approach that should be identified. First, as the germ cell population was ablated to allow a more robust analysis of the array data, it is possible that some of the transcripts are also expressed in germ cells although comparison to germ cell arrays from Johnston et al. (2008) would suggest that this number of transcripts is small (Supplementary Table 2). There is also the potential for off-target, secondary effects on other cells which might confuse the analysis. Prior ablation of the germ cells with busulphan, which does not significantly affect Leydig cell activity (O'Shaughnessy et al. 2008b), removed the most androgen-dependent cell population from the testis but significant changes in the remaining Sertoli cells and PTMCs would still be expected following the loss of androgen stimulation. However, any reduction in expression in these cells might be expected to be delayed, and it should be noted that expression of Rhox5, Cldn11, Drd4 and Eppin, putative androgen-dependent transcripts in the mouse (Lindsey \& Wilkinson 1996, O'Shaughnessy et al. 2007, Hu et al. 2010, Willems et al. 2010), did not show any change up to $20 \mathrm{~d}$ following EDS treatment (not shown). In contrast, Tubb3 and Cyp26b1, also proposed to be androgen dependent in the mouse ( $\mathrm{O}^{\prime}$ 'Shaughnessy et al. 2007, Willems et al. 2010), did show reduced expression after EDS treatment but with complex patterns of change, quite distinct from the canonical Leydig cell genes (Supplementary Table 1). Discrepancies between the published literature and the effects of EDS on these 
A
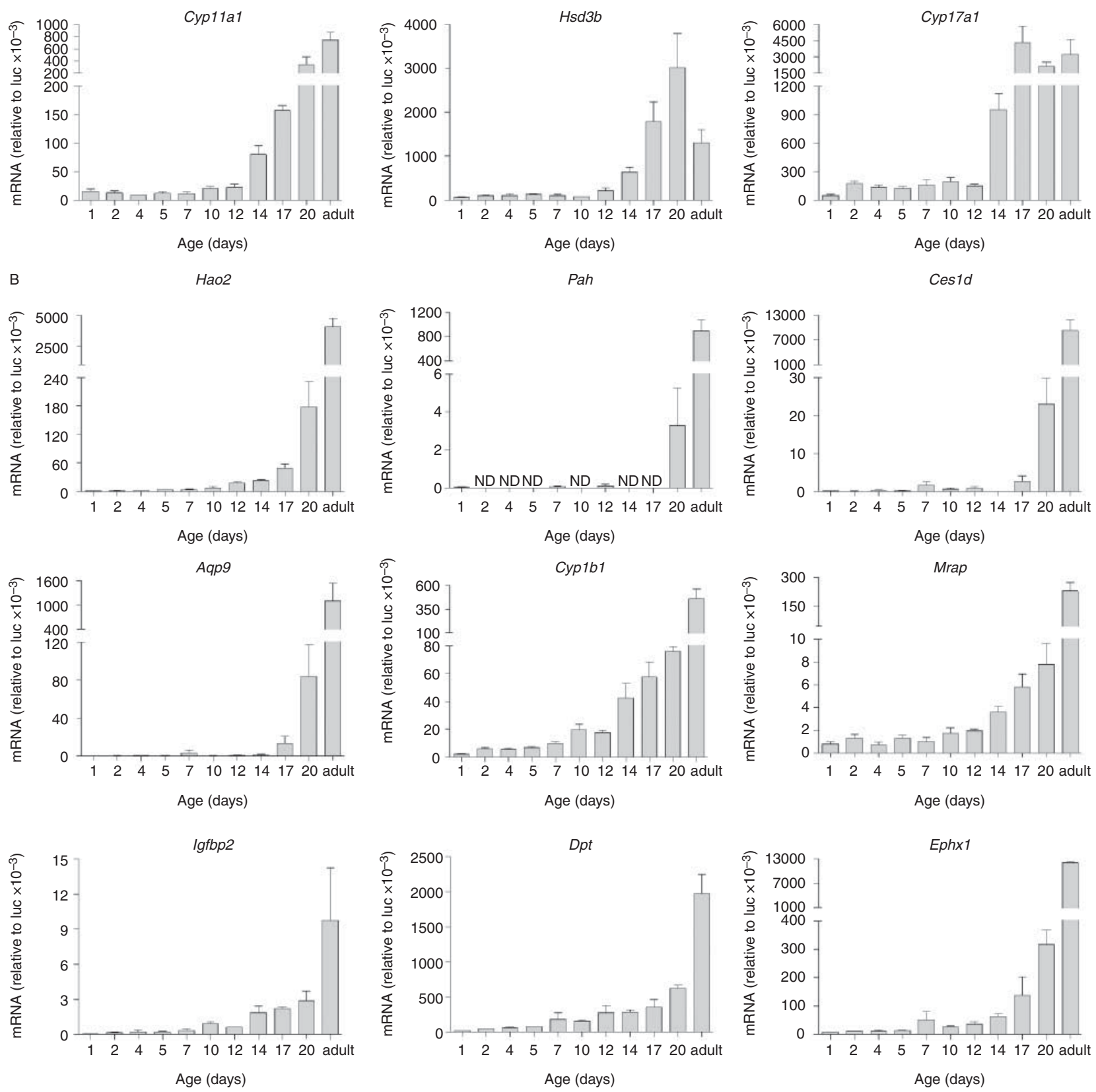

Figure 4 Developmental changes in Leydig cell transcripts. Testicular transcript levels were measured in rats of different ages relative to an external standard (luciferase). The mean \pm s.E.M. of between three and five animals per group is shown for canonical Leydig cell genes (A) and putative Leydig cell genes (B). ND, not detectable.

androgen-dependent transcripts may be due to species differences between rat and mouse (see below) or to other differences in the animal models used (e.g. altered androgen sensitivity in Sertoli cells following germ cell ablation). One last potential weakness of this technique is the possibility that EDS has direct effects on other cell types in the testis leading to alterations in specific transcript levels. This possibility cannot be ruled out although EDS is largely cleared from the testis within $24 \mathrm{~h}$ (Edwards et al. 1969), and it might be expected that transcript levels would tend to revert back towards normal (and so not be included in Table 1) unless a more permanent change had occurred in the target cell.

It is of interest that there are distinct differences in the lists of Leydig cell transcripts produced by the three experimental approaches described above. Best agreement is between the study of Stanley et al. (2011) and the current study with over $40 \%$ of the developmentally regulated Leydig cell genes also appearing in Table 1. This includes most of the top-ranked transcripts in 

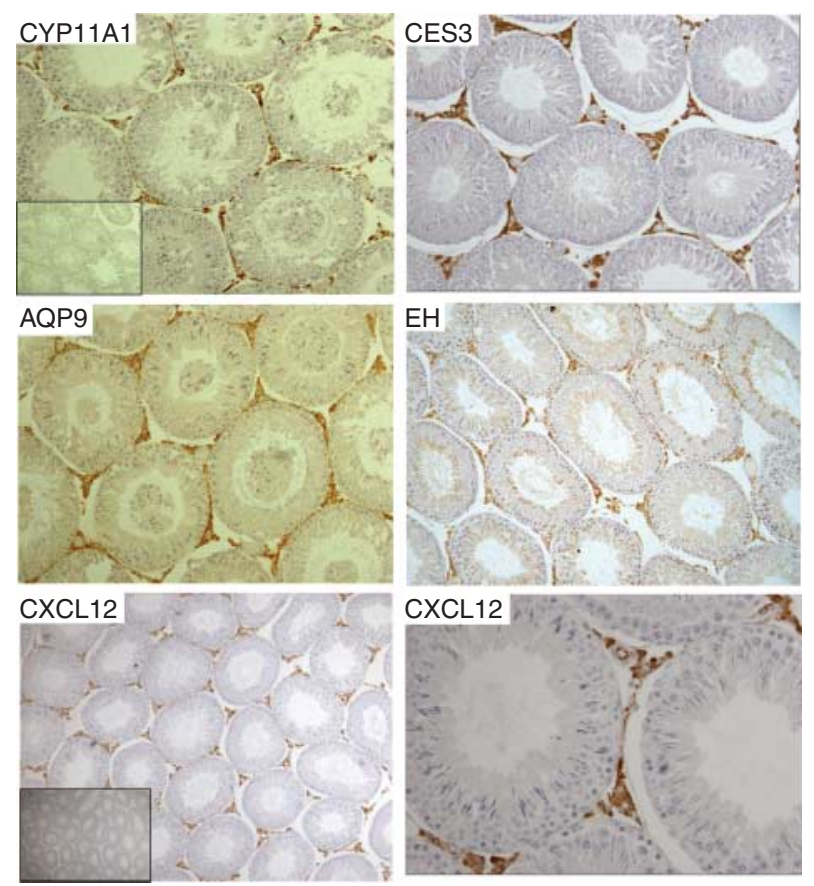

Figure 5 Expression of selected proteins in the adult rat testis. Testes from normal (untreated) adult rats were fixed in Bouin's solution and immunohistochemistry was used to localise expression. In each case, the proteins were localised exclusively or predominantly in the interstitial tissue. The insert to CYP11A1 shows a control without primary antibody. Another control is shown as an insert to CXCL12 as the primary antibody in this case was raised in mouse. No crossreactivity to the secondary antibody was seen.

Table 1, providing further confidence that these are Leydig cell-specific transcripts. Failure of the remaining $60 \%$ of developmentally regulated Leydig cell genes identified by Stanley et al. (2011) to show a significant change in expression after EDS treatment indicates that they are not specific to the Leydig cells in the testis and are probably also expressed elsewhere. The relative lack of overlap between the transcripts identified by Sanz et al. (2013) is most likely to be due to species differences, possible non-Leydig cell Cre expression in the Cyp17iCre mice and androgen-dependent changes in some non-Leydig cell transcripts following EDS treatment. Differences in the transcriptome between rats and mice will account for some variation - for example, Cyp4f4, Cyp2a3 and Cyp2t1 listed in Table 1 are specific to the rat genome, while four of the ten most highly enriched Leydig cell genes described in the study of Sanz et al. (2013) are specific to the mouse genome. There are also some known differences in Leydig cell function between the species (e.g. Gnrhr is expressed in the rat testis but not the mouse testis (Ishaq et al. 2013)), while a number of mouse transcripts in the Sanz et al. (2013) study showed low expression in the rat arrays so that any effect of EDS would be difficult to show (e.g. Fetub). Finally, it has been shown that elimination of Leydig cells by EDS can induce transcript expression by other cell types such as the Sertoli cells (Garcia-Galiano et al. 2012), so that these transcripts would not be identified as normally Leydig cell specific using the cell ablation technique described here.

The method/algorithm used in this study to identify Leydig cell transcripts was based on changes in expression of known canonical Leydig cell genes, such as Cyp11a1 and $H_{s d} 3 b$, although three known Leydig cell transcripts, Star, Ptgds and Sult1e1, did not fit the pattern. The STAR protein is an essential component of the steroid biosynthesis pathway (Clark et al. 1994), but the gradual decline in transcript levels following Leydig cell ablation suggests that other testicular cell types must also express Star. Earlier studies have shown that Star expression can be induced in Sertoli cells by follicle-stimulating hormone ( $\mathrm{FSH}$; Gregory \& DePhilips 1998), which would be consistent with results reported here as EDS treatment causes a significant increase in circulating FSH levels (Jackson \& Morris 1977, Molenaar et al. 1986). Previous studies have shown that Ptgds and Sult1e1 are expressed in mouse Leydig cells (Song et al. 1997, Baker \& O'Shaughnessy 2001 b). Levels of Ptgds declined after EDS treatment in this study, but only to about $50-60 \%$ of control (not shown), so that it did not fit the criteria for inclusion in Table 1. This would suggest that Ptgds is expressed in adult rat Leydig cells and, probably, also in another cell type. Expression of Sult1e1 was not detectable above background levels in any of the arrays in this study, suggesting that it is not expressed in the rat testis which would be consistent with the absence of identified expressed sequence tags in the rat testis (Unigene Rn.32104).

Proteins encoded by the transcripts listed in Supplementary Table 2 function in a variety of roles as detailed in Supplementary Figure 1, (see section on supplementary data given at the end of this article). Apart from canonical functions in steroid synthesis and metabolism, the most prominent functional group is involved in drug and xenotoxicant metabolism. This includes 15 of the 93 Leydig cell-specific transcripts in Table 1 and suggests that the Leydig cells may have significant capacity to protect the testis from exposure to harmful exogenous or endogenous agents. Previous studies have shown that the testes of various species show metabolic enzyme activity associated with carboxylesterase, CYP1B1, epoxide hydrolase and glutathione $S$-transferase, and the Leydig cells are likely, both from the previous work and from results reported here, to be the major contributors to this activity (Blackshaw 1970, DiBiasio et al. 1991, Otto et al. 1992, Ellis et al. 1998, Chen et al. 2004). A number of xenotoxicants have been shown to have selective reproductive toxicity in the rat (e.g. bisphenol A, phthalates, polyaromatic hydrocarbons, molinate) acting primarily on the Sertoli cells (Boekelheide et al. 2005) and Leydig cells (Ellis et al. 1998, Papadopoulos 2007) and leading to disruption of spermatogenesis. Xenobiotic metabolism by the Leydig cells may act to limit and reduce the effects of these, and other, compounds as 
suggested previously (DiBiasio et al. 1991). In addition to metabolic enzymes, the Leydig cells appear to secrete a number of active proteins such as haemopexin, haptoglobin and lactoperoxidase. Haptoglobin and haemopexin are acute-phase proteins typically secreted by the liver as a stress response (Guillouzo et al. 1984) though they are also secreted by other organs in response to acute injury (Zager et al. 2012). Both will act to reduce oxidative stress through antioxidant action or through haem binding (Tseng et al. 2004, Tolosano et al. 2010), while haemopexin also has potent anti-inflammatory effects (Fink 2009). Lactoperoxidase, in contrast, is a natural antibacterial agent usually associated with exocrine glands (Pruitt \& Reiter 1985). While these proteins have diverse actions, one functional link is that they would act to protect testicular function. Allied to the expression of metabolic enzymes by the Leydig cells, this suggests that a major function of the Leydig cells may be to maintain testicular function in the face of diverse potential challenges. Earlier studies, using an androgensupplemented EDS rat model, reported that testosterone is the only product of the Leydig cell essential for spermatogenesis (Sharpe et al. 1988). It would now be of interest to determine whether spermatogenesis in the absence of Leydig cells is more susceptible to the effects of xenotoxicants or other systemic challenges given the likely protective role played by these cells.

Results from this study show that the chemokine CXCL12 is expressed primarily in the Leydig cells of the adult rat testis with no expression apparent in the tubules. This is surprising as previous studies have reported that CXCL12 is produced by the Sertoli cells in the mouse testis and that it is required for migration of the primordial germ cells (PGC) to the tubules and for maintenance of the PGC and spermatogonial stem cells in the Sertoli cell niche (Molyneaux et al. 2003, Payne et al. 2010, Yang et al. 2013). However, the EDS and immunohistochemical data from the rat are clear, and differences in reported mouse studies are, presumably, species related. It has been reported that mouse Leydig cells secrete CSF1 which acts to increase SSC self-renewal (Oatley et al. 2009), thereby suggesting that the adult Leydig cells may be a major contributor to the SSC niche. However, in our arrays, Csf1 transcript levels were not altered by EDS treatment, which indicates that it is unlikely to be a Leydig cell product in the rat. Overall, data from this study support the hypothesis that the Leydig cells contribute to the SSC niche although the nature of that support may vary between species.

Results in Table 1 (and Supplementary Figure 1) identify a number of receptors apparently associated with the Leydig cells. Receptors for $\mathrm{LH}$, prolactin and GNRH have all been shown in earlier studies to be expressed in rat Leydig cells (Zhang et al. 1995, Ariyaratne et al. 2000, Ishaq et al. 2013), but others have not been described previously. GPR182 is an adrenomedullin receptor that mediates a cAMP response to the peptide (Kapas et al. 1995). Adrenomedullin is reported to be expressed in Sertoli cells and Leydig cells and to inhibit LH/hCG stimulation of testosterone production by the testis ( $\mathrm{Li}$ et al. 2006, Chan et al. 2008) although the effect does not appear to be marked. CD36 is a cellular membrane glucoprotein and a member of the class B scavenger receptor family. Among other things, CD36 acts to facilitate fatty acid and lipoprotein uptake (He et al. 2011) and so may contribute to the cellular pool of cholesterol esters. MRAP is essential for trafficking and functional expression of the ACTH receptor MC2R in the adrenal gland (Novoselova et al. 2013). MC2R is functionally expressed in foetal Leydig cells in the mouse testis (O'Shaughnessy et al. 2003) but not in adult Leydig cells, and there is no evidence of Mc2r expression in adult rat Leydig cells from this study. Therefore, the function of MRAP in adult rat Leydig cells is unclear, but MRAP can interact with other melanocortin receptors and it is possible that it may be involved in the functional expression of other GPRs.

Results in Fig. 4 show that transcripts encoding steroidogenic enzymes reach adult levels by about 20 days of age in the rat. Enzyme activity per se starts to increase at about the same age in the rat testis (Inano et al. 1967, Goldman \& Klingele 1974, Payne et al. 1977), while circulating androgen levels start to rise between day 20 and 30 (Piacsek \& Goodspeed 1978). Interestingly, the non-canonical Leydig cell-specific transcripts that were tested in this study showed both a slow recovery after EDS treatment and a later developmental increase in expression to adult levels. This is consistent with a staged maturation process in the adult Leydig cells described by others (Ge et al. 2005, Stanley et al. 2011) and suggests that these additional functions may develop to ensure optimal androgen production in adulthood and to protect the developing spermatogenic population.

The Leydig cells are essential regulators of testicular function, fertility and male behaviour. Results from this study identify the key transcripts specifically associated with these cells and show that the main function of the cells, apart from androgen production, is likely to be to protect the testis from toxicant exposure and stress. The approach used also highlights the potential and advantages of using cell ablation to identify cell-specific transcripts.

\section{Supplementary data}

This is linked to the online version of the paper at http://dx.doi. org/10.1530/REP-13-0603.

\section{Declaration of interest}

The authors declare that there is no conflict of interest that could be perceived as prejudicing the impartiality of the research reported. 


\section{Funding}

This research did not receive any specific grant from any funding agency in the public, commercial or not-for-profit sector.

\section{Acknowledgements}

We thank Prof. Dr Ulrich M Zanger and Prof. A H Payne (deceased) for provision of antibody.

\section{References}

Ariyaratne HB, Mendis-Handagama SM, Hales DB \& Mason JI 2000 Studies of the onset of Leydig precursor cell differentiation in the prepubertal rat testis. Biology of Reproduction 63 165-171. (doi:10. 1095/biolreprod63.1.165)

Baker PJ \& O'Shaughnessy PJ 2001a Role of gonadotrophins in regulating numbers of Leydig and Sertoli cells during fetal and postnatal development in mice. Reproduction 122 227-234. (doi:10.1530/rep.0.1220227)

Baker PJ \& O'Shaughnessy PJ 2001b Expression of prostaglandin D synthetase during development in the mouse testis. Reproduction 122 553-559. (doi:10.1530/rep.0.1220553)

Baker PJ, Sha JA, McBride MW, Peng L, Payne AH \& O'Shaughnessy PJ 1999 Expression of 3ß-hydroxysteriod dehydrogenase type I and VI isoforms in the mouse testis during development. European Journal of Biochemistry 260 911-916. (doi:10.1046/j.1432-1327.1999.00245.x)

Baker PJ, Pakarinen P, Huhtaniemi IT, Abel MH, Charlton HM, Kumar TR \& O'Shaughnessy PJ 2003a Failure of normal Leydig cell development in follicle-stimulating hormone (FSH) receptor-deficient mice, but not FSH $\beta$-deficient mice: role for constitutive FSH receptor activity. Endocrinology 144 138-145. (doi:10.1210/en.2002-220637)

Baker PJ, Johnston H, Abel MH, Charlton HM \& O'Shaughnessy PJ $2003 b$ Differentiation of adult-type Leydig cells occurs in gonadotrophindeficient mice. Reproductive Biology and Endocrinology 1 4. (doi:10. 1186/1477-7827-1-4)

Blackshaw A 1970 Localisation of testicular enzymes. In The Testis, II Biochemistry, pp 94-103. Ed. A Johnson. New York: Academic Press.

Boekelheide K, Johnson K \& Richburg J 2005 Sertoli cell toxicants. In Sertoli Cell Biology, pp 345-382. Eds MK Skinner\& MD Griswold. Amsterdam: Elsevier.

Breitling R, Armengaud P, Amtmann A \& Herzyk P 2004 Rank products: a simple, yet powerful, new method to detect differentially regulated genes in replicated microarray experiments. FEBS Letters 573 83-92.

Chan YF, WS O \& Tang F 2008 Adrenomedullin in the rat testis. I: its production, actions on testosterone secretion, regulation by human chorionic gonadotropin, and its interaction with endothelin 1 in the Leydig cell. Biology of Reproduction 78 773-779. (doi:10.1095/ biolreprod.107.060871)

Chen H, Irizarry RA, Luo L \& Zirkin BR 2004 Leydig cell gene expression: effects of age and caloric restriction. Experimental Gerontology 39 31-43. (doi:10.1016/j.exger.2003.09.021)

Clark BJ, Wells J, King SR \& Stocco DM 1994 The purification, cloning and expression of a novel $\mathrm{LH}$-induced mitochondrial protein in MA-10 mouse Leydig tumor cells. Characterization of the steroidogenic acute regulatory protein (StAR). Journal of Biological Chemistry 269 28314-28322.

Coller JK, Fritz P, Zanger UM, Siegle I, Eichelbaum M, Kroemer HK \& Murdter TE 2001 Distribution of microsomal epoxide hydrolase in humans: an immunohistochemical study in normal tissues, and benign and malignant tumours. Histochemical Journal 33 329-336. (doi:10.1023/A:1012414806166)

Czechowski T, Bari RP, Stitt M, Scheible WR \& Udvardi MK 2004 Realtime RT-PCR profiling of over 1400 Arabidopsis transcription factors: unprecedented sensitivity reveals novel root- and shoot-specific genes. Plant Journal 38 366-379. (doi:10.1111/j.1365-313X.2004.02051.x)

DiBiasio KW, Silva MH, Shull LR, Overstreet JW, Hammock BD \& Miller MG 1991 Xenobiotic metabolizing enzyme activities in rat, mouse, monkey, and human testes. Drug Metabolism and Disposition 19 227-232.
Edwards K, Craig AW, Jackson H \& Jones AR 1969 Studies with alkylating esters. I. The fate of ethylene dimethanesulphonate. Biochemical Pharmacology 18 1693-1700. (doi:10.1016/0006-2952(69)90158-0)

Ellis MK, Richardson AG, Foster JR, Smith FM, Widdowson PS, Farnworth MJ, Moore RB, Pitts MR \& Wickramaratne GA 1998 The reproductive toxicity of molinate and metabolites to the male rat: effects on testosterone and sperm morphology. Toxicology and Applied Pharmacology 151 22-32. (doi:10.1006/taap.1998.8371)

Fink MP 2009 Editorial: hemopexin: newest member of the antiinflammatory mediator club. Journal of Leukocyte Biology 86 203-204. (doi:10.1189/jlb.0309137)

Garcia-Galiano D, Pineda R, Ilhan T, Castellano JM, Ruiz-Pino F, SanchezGarrido MA, Vazquez MJ, Sangiao-Alvarellos S, Romero-Ruiz A, Pinilla L et al. 2012 Cellular distribution, regulated expression, and functional role of the anorexigenic peptide, NUCB2/nesfatin-1, in the testis. Endocrinology 153 1959-1971. (doi:10.1210/en.2011-2032)

Ge RS, Dong Q, Sottas CM, Chen H, Zirkin BR \& Hardy MP 2005 Gene expression in rat Leydig cells during development from the progenitor to adult stage: a cluster analysis. Biology of Reproduction 72 1405-1415. (doi:10.1095/biolreprod.104.037499)

Gilbert DC, Chandler I, McIntyre A, Goddard NC, Gabe R, Huddart RA \& Shipley J 2009 Clinical and biological significance of CXCL12 and CXCR4 expression in adult testes and germ cell tumours of adults and adolescents. Journal of Pathology 217 94-102. (doi:10.1002/path.2436)

Goldman AS \& Klingele DA 1974 Developmental defects of testicular morphology and steroidogenesis in the male rat pseudohermaphrodite and response to testosterone and dihydrotestosterone. Endocrinology 94 1-16. (doi:10.1210/endo-94-1-1)

Gregory CW \& DePhilips RM 1998 Detection of steroidogenic acute regulatory protein $(\mathrm{StAR})$ in mitochondria of cultured rat Sertoli cells incubated with follicle-stimulating hormone. Biology of Reproduction $\mathbf{5 8}$ 470-474. (doi:10.1095/biolreprod58.2.470)

Guillouzo A, Delers F, Clement B, Bernard N \& Engler R 1984 Long term production of acute-phase proteins by adult rat hepatocytes co-cultured with another liver cell type in serum-free medium. Biochemical and Biophysical Research Communications 120 311-317. (doi:10.1016/ 0006-291X(84)91255-5)

He J, Lee JH, Febbraio M \& Xie W 2011 The emerging roles of fatty acid translocase/CD36 and the aryl hydrocarbon receptor in fatty liver disease. Experimental Biology and Medicine 236 1116-1121. (doi:10.1258/ebm.2011.011128)

Holmes RS, Wright MW, Laulederkind SJ, Cox LA, Hosokawa M, Imai T, Ishibashi S, Lehner R, Miyazaki M, Perkins EJ et al. 2010 Recommended nomenclature for five mammalian carboxylesterase gene families: human, mouse, and rat genes and proteins. Mammalian Genome 21 427-441. (doi:10.1007/s00335-010-9284-4)

Hu Z, Dandekar D, O'Shaughnessy PJ, De GK, Verhoeven G \& Wilkinson MF 2010 Androgen-induced Rhox homeobox genes modulate the expression of AR-regulated genes. Molecular Endocrinology 24 60-75. (doi:10.1210/me.2009-0303)

Inano H, Hori Y \& Tamaoki B 1967 Effect of age on testicular enzymes related to steroid bioconversion. Ciba Foundation Colloquia on Endocrinology 16 105-117.

Irizarry RA, Hobbs B, Collin F, Beazer-Barclay YD, Antonellis KJ, Scherf U \& Speed TP 2003 Exploration, normalization, and summaries of high density oligonucleotide array probe level data. Biostatistics 4 249-264.

Ishaq M, Schang AL, Magre S, Laverriere JN, Guillou A, Coudouel N, Wargnier R, Cohen-Tannoudji J \& Counis R 2013 Rat Gnrhr promoter directs species-specific gene expression in the pituitary and testes of transgenic mice. Journal of Molecular Endocrinology 50 411-426. (doi:10.1530/JME-12-0231)

Ishii-Ohba H, Guengerich FP \& Baron J 1984 Localization of epoxidemetabolizing enzymes in rat testis. Biochimica et Biophysica Acta $\mathbf{8 0 2}$ 326-334. (doi:10.1016/0304-4165(84)90179-X)

Jackson CM \& Jackson H 1984 Comparative protective actions of gonadotrophins and testosterone against the antispermatogenic action of ethane dimethanesulphonate. Journal of Reproduction and Fertility 71 393-401. (doi:10.1530/jrf.0.0710393)

Jackson CM \& Morris ID 1977 Gonadotrophin levels in male rats following impairment of Leydig cell function by ethylene dimethanesulphonate. Andrologia 9 29-35. (doi:10.1111/j.1439-0272.1977.tb01255.x) 
Johnston H, Baker PJ, Abel M, Charlton HM, Jackson G, Fleming L, Kumar TR \& O'Shaughnessy PJ 2004 Regulation of Sertoli cell number and activity by follicle-stimulating hormone and androgen during postnatal development in the mouse. Endocrinology 145 318-329. (doi:10.1210/en.2003-1055)

Johnston DS, Wright WW, DiCandeloro P, Wilson E, Kopf GS \& Jelinsky SA 2008 Stage-specific gene expression is a fundamental characteristic of rat spermatogenic cells and Sertoli cells. PNAS 105 8315-8320. (doi:10.1073/pnas.0709854105)

Kapas S, Catt KJ \& Clark AJ 1995 Cloning and expression of cDNA encoding a rat adrenomedullin receptor. Journal of Biological Chemistry 270 25344-25347. (doi:10.1074/jbc.270.43.25344)

Kerr JB, Donachie K \& Rommerts FFG 1985 Selective destruction and regeneration of rat Leydig cells in vivo. A new method for the study of seminiferous tubular-interstitial tissue interaction. Cell and Tissue Research 242 145-156. (doi:10.1007/BF00225571)

Li YY, Hwang IS, WS O \& Tang F 2006 Adrenomedullin peptide: gene expression of adrenomedullin, its receptors and receptor activity modifying proteins, and receptor binding in rat testis - actions on testosterone secretion. Biology of Reproduction 75 183-188. (doi:10. 1095/biolreprod.106.052274)

Lindsey JS \& Wilkinson MF 1996 Pem: a testosterone-regulated and LH-regulated homeobox gene expressed in mouse Sertoli cells and epididymis. Developmental Biology 179 471-484. (doi:10.1006/dbio. 1996.0276)

Molenaar R, de Rooij DG, Rommerts FFG \& van der Molen HJ 1986 Repopulation of Leydig cells in mature rats after selective destruction of the existent Leydig cells with ethylene dimethane sulfonate is dependent on luteinizing hormone and not follicle-stimulating hormone. Endocrinology 118 2546-2554. (doi:10.1210/endo-118-6-2546)

Molyneaux KA, Zinszner H, Kunwar PS, Schaible K, Stebler J, Sunshine MJ, O'Brien W, Raz E, Littman D, Wylie C et al. 2003 The chemokine SDF1/CXCL12 and its receptor CXCR4 regulate mouse germ cell migration and survival. Development 130 4279-4286. (doi:10.1242/dev.00640)

Morris ID, Phillips DM \& Bardin CW 1986 Ethylene dimethanesulfonate destroys Leydig cells in the rat testis. Endocrinology 118 709-719. (doi:10.1210/endo-118-2-709)

Nef S, Shipman T \& Parada LF 2000 A molecular basis for estrogen-induced cryptorchidism. Developmental Biology 224 354-361. (doi:10.1006/ dbio.2000.9785)

Novoselova TV, Jackson D, Campbell DC, Clark AJ \& Chan LF 2013 Melanocortin receptor accessory proteins in adrenal gland physiology and beyond. Journal of Endocrinology 217 R1-11. (doi:10.1530/JOE-12-0501)

Oatley JM, Oatley MJ, Avarbock MR, Tobias JW \& Brinster RL 2009 Colony stimulating factor 1 is an extrinsic stimulator of mouse spermatogonial stem cell self-renewal. Development 136 1191-1199. (doi:10.1242/dev.032243)

O'Shaughnessy PJ \& Mannan MA 1994 Development of cytochrome P-450 side chain cleavage mRNA levels in neonatal ovaries of normal and hypogonadal (hpg) mice. Molecular and Cellular Endocrinology 104 133-138. (doi:10.1016/0303-7207(94)90115-5)

O'Shaughnessy PJ \& Murphy L 1993 Cytochrome P-450 17 $\alpha$-hydroxylase protein and mRNA in the testis of the testicular feminized (Tfm) mouse. Journal of Molecular Endocrinology 11 77-82. (doi:10.1677/jme.0. 0110077)

O'Shaughnessy PJ, Willerton L \& Baker PJ 2002 Changes in Leydig cell gene expression during development in the mouse. Biology of Reproduction 66 966-975. (doi:10.1095/biolreprod66.4.966)

O'Shaughnessy PJ, Fleming LM, Jackson G, Hochgeschwender U, Reed P \& Baker PJ 2003 Adrenocoricotrophic hormone directly stimulates testosterone production by the fetal and neonatal mouse testis. Endocrinology 144 3279-3284. (doi:10.1210/en.2003-0277)

O'Shaughnessy PJ, Abel M, Charlton HM, Hu B, Johnston H \& Baker PJ 2007 Altered expression of genes involved in regulation of vitamin a metabolism, solute transportation, and cytoskeletal function in the androgen-insensitive tfm mouse testis. Endocrinology 148 2914-2924. (doi:10.1210/en.2006-1412)

O'Shaughnessy PJ, Morris ID \& Baker PJ 2008a Leydig cell re-generation and expression of cell signaling molecules in the germ cell-free testis. Reproduction 135 851-858. (doi:10.1530/REP-07-0529)

O'Shaughnessy PJ, Hu L \& Baker PJ $2008 b$ Effect of germ cell depletion on levels of specific mRNA transcripts in mouse Sertoli cells and Leydig cells. Reproduction 135 839-850. (doi:10.1530/REP-08-0012)
Otto S, Bhattacharyya KK \& Jefcoate CR 1992 Polycyclic aromatic hydrocarbon metabolism in rat adrenal, ovary, and testis microsomes is catalyzed by the same novel cytochrome P450 (P450RAP). Endocrinology 131 3067-3076.

Papadopoulos V 2007 Environmental factors that disrupt Leydig cell steroidogenesis. In Leydig Cell in Health and Disease, pp 393-413. Eds AH Payne\& MP Hardy. Totowa: Humana Press.

Payne AH, Kelch RP, Murono EP \& Kerlan JT 1977 Hypothalamic, pituitary and testicular function during sexual maturation of the male rat. Journal of Endocrinology 72 17-26. (doi:10.1677/joe.0.0720017)

Payne CJ, Gallagher SJ, Foreman O, Dannenberg JH, Depinho RA \& Braun RE 2010 Sin3a is required by Sertoli cells to establish a niche for undifferentiated spermatogonia. Germ cell tumors, and spermatid elongation. Stem Cells 28 1424-1434. (doi:10.1002/stem.464)

Piacsek BE \& Goodspeed MP 1978 Maturation of the pituitary-gonadal system in the male rat. Journal of Reproduction and Fertility 52 29-35. (doi:10.1530/jrf.0.0520029)

Pruitt K \& Reiter B 1985 Biochemistry of peroxidase systems: antomicrobial effects. In The Lactoperoxidase System: Chemistry and Biological Significance, pp143-178. Eds KM Pruitt \& JO Tenovuo New York: Crc Press.

Pusch W, Balvers M \& Ivell R 1996 Molecular cloning and expression of the relaxin-like factor from the mouse testis. Endocrinology 137 3009-3013.

Roberts V, Meunier H, Sawchenko PE \& Vale W 1989 Differential production and regulation of inhibin subunits in rat testicular cell types. Endocrinology 125 2350-2359. (doi:10.1210/endo-125-5-2350)

Sanz E, Evanoff R, Quintana A, Evans E, Miller JA, Ko C, Amieux PS, Griswold MD \& McKnight GS 2013 RiboTag analysis of actively translated mRNAs in Sertoli and Leydig cells in vivo. PLoS ONE 8 e66179. (doi:10.1371/journal.pone.0066179)

Sharpe RM, Fraser HM \& Ratnasooriya WD 1988 Assessment of the role of Leydig cell products other than testosterone in spermatogenesis and fertility in adult rats. International Journal of Andrology 11 507-523. (doi:10.1111/j.1365-2605.1988.tb01024.x)

Song WC, Qian Y, Sun X \& Negishi M 1997 Cellular localization and regulation of expression of testicular estrogen sulfotransferase. Endocrinology 138 5006-5012. (doi:10.1210/endo.138.11.5512)

Stanley EL, Johnston DS, Fan J, Papadopoulos V, Chen H, Ge RS, Zirkin BR \& Jelinsky SA 2011 Stem Leydig cell differentiation: gene expression during development of the adult rat population of Leydig cells. Biology of Reproduction 85 1161-1166. (doi:10.1095/biolreprod.111.091850)

Tolosano E, Fagoonee S, Morello N, Vinchi F \& Fiorito V 2010 Heme scavenging and the other facets of hemopexin. Antioxidants \& Redox Signaling 12 305-320. (doi:10.1089/ars.2009.2787)

Tseng CF, Lin CC, Huang HY, Liu HC \& Mao SJ 2004 Antioxidant role of human haptoglobin. Proteomics 4 2221-2228. (doi:10.1002/pmic. 200300787)

Vergouwen RPFA, Huiskamp R, Bas RJ, Roepers-Gajadien HL, Davids JAG \& de Rooij DG 1993 Postnatal development of testicular populations in mice. Journal of Reproduction and Fertility 99 479-485.

Willems A, De Gendt K, Allemeersch J, Smith LB, Welsh M, Swinnen JV \& Verhoeven G 2010 Early effects of Sertoli cell-selective androgen receptor ablation on testicular gene expression. International Journal of Andrology 33 507-517.

Yang QE, Kim D, Kaucher A, Oatley MJ \& Oatley JM 2013 CXCL12-CXCR4 signaling is required for the maintenance of mouse spermatogonial stem cells. Journal of Cell Science 126 1009-1020. (doi:10.1242/jcs.119826)

Zager RA, Johnson AC \& Becker K 2012 Renal cortical hemopexin accumulation in response to acute kidney injury. American Journal of Physiology. Renal Physiology 303 F1460-F1472. (doi:10.1152/ajprenal.00426.2012)

Zhang FP, Rannikko A, Toppari J, Bartke A \& Huhtaniemi I 1995 Developmental expression of the prolactin receptor gene in rat gonads. Journal of Endocrinology 147 497-505. (doi:10.1677/joe.0.1470497)

Received 24 November 2013

First decision 17 December 2013

Revised manuscript received 3 February 2014

Accepted 6 February 2014 